\title{
CIÊNCIANATURA
}

\section{Importance of the review on floristic and phytosociological studies of the arboreal stratum of the seasonal deciduous forest of the Serra Geral slope, Rio Grande do Sul, Brazil, to support proposals for sustainable management}

\author{
Importância da revisão sobre estudos florísticos e fitossociológicos do estrato arbóreo da \\ floresta estacional decidual da fralda da Serra Geral, Rio Grande do Sul, Brasil, para \\ embasamento de propostas de manejo sustentável
}

Cristian Mateus Zerwes ${ }^{1}$, Claudete Rempel ${ }^{2}$, Janaina Kollet Schneider ${ }^{3}$ e Leila Teresinha Maranho ${ }^{4}$

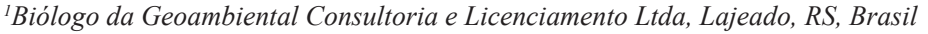 \\ ${ }^{2}$ Universidade do Vale do Taquari - Univates, Lajeado, RS, Brasil \\ ${ }^{3}$ Colégio Sinodal Gustavo Adolfo, Lajeado, RS, Brasil \\ ${ }^{4}$ Universidade Positivo, Curitiba, Paraná, Brasil
}

\begin{abstract}
The Seasonal Deciduous Forest (SDF) is a deciduous and human-caused impacted vegetation, occurring at the Upper Uruguay river basin and at the southern slope of Serra Geral plateau, Rio Grande do Sul state. The aim of this study is to compile results of tree layer floristics and phytosociological surveys on SDF of Serra Geral escarpment with the intention of supporting future interventions for the recovery of degraded areas and sustainable management projects. To obtain the data, was held a narrative review from 62 selected works from the digital libraries of CAPES, Scielo and Google Scholar. For quantitative variables, was calculated the median, standard deviation and amplitude. The hodgepodge of methods used in the surveys conducts to difficulties in comparing data. The median species richness is 54 and the Shannon-Wiener diversity index median is 3.10. The analyzed surveys show very important information to define methods and planning for conservation, degraded area recovery and sustainable use of forest resources.
\end{abstract}

Keywords: Biodiversity. Atlantic Forest. Subtropical forest. Woody vegetation.

\section{Resumo}

A Floresta Estacional Decidual (FED) é uma vegetação caducifólia impactada antropicamente, que ocorre na região do Alto Uruguai e na encosta meridional da Serra Geral do Rio Grande do Sul (RS). Este estudo objetiva compilar resultados de levantamentos florísticos e fitossociológicos do estrato arbóreo na FED da Fralda da Serra Geral do RS com o intuito de embasar futuras intervenções para recuperação de áreas degradadas e projetos de manejo sustentável. Para a obtenção dos dados, realizou-se uma revisão narrativa a partir de 62 trabalhos selecionados dos portais de periódicos da CAPES, Scielo e Google Acadêmico. Para as variáveis quantitativas, calculou-se a mediana, desvio-padrão e amplitude. A miscelânea de métodos empregados nos levantamentos gera dificuldades na comparação entre os dados. A riqueza mediana é de 54 espécies e o indice de diversidade de Shannon-Wiener mediano é de 3,10. Os estudos analisados apresentam informações de suma importância para definição de métodos e planejamento para conservação, recuperação de áreas degradadas e uso sustentável dos recursos florestais.

Palavras-Chave: Biodiversidade. Mata Atlântica. Floresta subtropical. Vegetação arbórea. 


\section{Introduction}

Phytosociological studies are essential for understanding the dynamics of plant populations and their relationship with biotic and abiotic factors, which serve as the basis for conservation projects, restoration of degraded areas and sustainable management of forest resources. In addition, they can be used to determine the degree of degradation of an environment (ZERWES, 2016).

In this way, an ecosystem threatened by human action lacks accurate, current and readily available data to the scientific community, decision makers and anyone interested in the subject. Based on this, the present review was elaborated, considering that seasonal forests are the phytophysiognomy most threatened in the world due to historical and current anthropogenic intervention (KILCA; LONGHI, 2011a). In Brazil, a classification category of this vegetation is Floresta Estacional Decidual (SDF - Seasonal Deciduous Forest), which is distributed in different parts of the country, being included in the Atlantic Forest Biome (IBGE, 2012). In addition, this biome is also threatened and is considered one of the biodiversity priority hotspots for conservation (MYERS et al., 2000), due to the current and historical degradation, by the exploitation of wood and wild animals, leaving only $27 \%$ of the original biome (SCHÄFFER, 2000). Specifically on the SDF, Cordeiro and Hasenack (2009) found that only $17.97 \%$ of the vegetation cover still remains in Rio Grande do Sul (RS).

However, over the last decades, the literature indicates an increase in forest vegetation in RS: in 1982, 5.62\% of RS territory was occupied by native forests (BRENA, 2001); in 1990, there were only 4.2\% of the original SDF area in RS (LEITE; KLEIN, 1990) and in 2000, native forests already occupied 17.53\% of RS (BRENA, 2001). Cordeiro and Hasenack (2009) affirm that there was an increase of $24.72 \%$ in the SDF between the RADAMBRASIL Project from the 1980s and 2002, a fact that can be justified by the rural exodus. Hirota and Ponzoni (2014) point out that in the RS, of the area occupied by the Atlantic Forest Biome, there are currently $7.29 \%$ of native forests and $12.9 \%$ of total native vegetation (including savannah), with deforestation rates decreasing in comparison to the decades above. It should be noted that this increment does not represent regeneration of the original forest, and in many cases, it is an increment of SDF in the initial secondary stage of regeneration (REMPEL; SUERTEGARAY; JASPER, 2001), since the forested area of RS in the year $2000\left(49,556.29 \mathrm{~km}^{2}\right), 23 \%$ were in the initial stage (BRENA, 2001).

In Rio Grande do Sul, forests were originally concentrated in the north, in Alto Uruguay, and on the southern slopes of Serra Geral (MARCHIORI, 2002). From these forest formations, they can be classified as Deciduous Seasonal Forest, those occurring in the northwestern Uruguay river basin, most of the southern slope of Serra Geral and in the areas dispersed by the Ijuí, Ibicuí and Jacuí river basins (LEITE; KLEIN, 1990).

This classification includes forests with a higher stratum formed by predominantly deciduous trees, with more than $50 \%$ of individuals without foliage in the unfavorable period (IBGE, 2012). Although in the State of Rio Grande do Sul, this is a typical ombrophilous forest, where the climate does not have a defined dry period and with enough rainfall intensity and regularity, is the period of two to three months, centered in the winter, with averages equal or inferior to $15^{\circ} \mathrm{C}$ (LEITE; KLEIN, 1990), which determines the condition unfavorable to growth. Although it is a humid winter, frost and low temperatures generate restrictions on the development of several typically tropical species, determining a rest in growth, such as the partial fall of foliage (IBGE, 2012). It is important to mention that the classification of this forest into SDF is not a consensus among researchers; Schumacher et al. (2011a) states that there is still a need for floristic and phenological studies to determine which RS forests are deciduous and semi-deciduous, proposing to use the term "Subtropical Seasonal Forest".

The Continuous Forest Inventory of RS (BRENA, 2001) report that in the RS, the SDF has two partitions: Alto Uruguay and the Southern Hills of Serra Geral. The latter comprises the focus of this review. The SDF of Serra Geral slope was distributed from western RS, near the Itú river, a tributary of the Ibicuí river, to the region near Osório, reaching the entire Serra Geral, and only widening along the rivers; is limited with the savannahs and steppes of the Pampas to the south and the Serra Geral plateau to the north (BRENA, 2001). This forest advanced on field areas on the Serra Geral slope, with the end of the glaciation period of 10,000 years ago, being colonized by species from two migratory corridors, the west and the east, considering that the altitude of the plateau prevents a colonization by the north (SCIPIONI, 2012).

The species of the western migratory contingent or Alto Uruguay are typical of the Decidual Seasonal Forest, which entered the northwest of the RS, through the Argentine province of Misiones (RAMBO, 1994), thus, an extension of the forest of the Paraná river basin with lower participation of tropical species (LEITE; KLEIN, 1990). Many of these species are emergent deciduous Fabaceae, which give vegetation the decidual aspect (JARENKOW; WAECHTER, 2001). The other corridor, east, consists of species typical of the Dense Ombrophylous Forest, which entered the RS through Torres, a narrow strip of land of approximately $25 \mathrm{~km}$ between the Atlantic Ocean and Aparados da Serra canyons (RAMBO, 1994), Many of which are typical of the understory (JARENKOW, WAECHTER, 2001). In addition, there is also the interpenetration of some species from the Ombrophilous Mixed Forest of Serra Geral (in the northern plateau), as well as Chaco-Pampa, Austral-Antarctic and Andean species (SCIPIONI, 2012; JARENKOW; WAECHTER, 2001).

Brena (2001) reports that in the original vegetation of the SDF, it is possible to distinguish the edge of the forest, the marginal strip and the high forest (forest itself). The edge of the forest is composed of shrubs and herbs, with emphasis on the shrub supporting Chusquea ramosissima Lindm. The marginal strip consists of shrubs and saplings such as Actinostemon concolor (Spreng.) Müll. Arg., Sorocea bonplandii (Baill.) W. C. Burger, Lanjouw \& Boer, Urera baccifera (L.) Gaudich. ex Wedd., Abutilon spp. and Boehmeria spp. Already the high forest, is composed of five layers. In the vegetation of soil, they occur Adiantum spp., grasses, shrubs and herbs 
of small height. In the low forest occur individuals of A. concolor, S. bonplandii, C. ramosissima, Piper spp., Celtis spinosa Spreng., U. baccifera and Trichilia elegans A. Juss. The stratum of the vines is represented by specimens of Mikania spp., Aristolochia spp., Smilax spp., Dolichandra unguis-cati (L.) LG Lohmann, Fridericia chica (Bonpl.) LG Lohmann, Cuspidaria spp., Serjania spp., Paullinia Spp. and Phanera microstachya (Raddi) L. P. Queiroz. Among the epiphytes are Cattleya spp., Brasilidium spp., Rhipsalis spp., Tillandsia spp., mosses and lichens. In the high forest, the trees Phytolacca dioica L., Zanthoxylum spp., Cedrela fissilis Vell., Cabralea canjerana (Vell.) Mart., Cordia trichotoma (Vell.) Arráb. ex Steud., Myrocarpus frondosus Allemão, Parapiptadenia rigida (Benth.) Brenan, Apuleia leiocarpa (Vogel) J.F. Macbr., Enterolobium contortisiliquum (Vell.) Morong, Luehea divaricata Mart. \& Zucc., Cordia americana (L.) Gottschling \& J. S. Mill., Ocotea spp., Nectandra spp. and Vitex megapotamica (Spreng.) Moldenke (BRENA, 2001).

Brena (2001) also points out that the secondary forests, resulting from abandoned crops, are initially constituted by individuals of Solanum mauritianum Scop., Trema micrantha (L.) Blume and Baccharis dracunculifolia DC. Over the years, also occur individuals of Inga marginata Willd., P. rigida, Ocotea spp., Nectandra spp. and Bauhinia forficata Link.

In addition to the classification between the Alto Uruguay and the Serra Geral slope formations, the literature classifies the SDF of RS in the following types of formations: alluvial, submontane and montane (IBGE, 2012; MARCHIORI, 2002). The alluvial type is represented by the riparian forests of the Jacuí, Ibicuí and Santa Maria rivers, with a general occurrence of deciduous hygrophyte species, adapted to the alluvial environment, L. divaricata, V. megapotamica, Inga vera Willd., Ruprechtia laxiflora Meisn. and Gymnanthes klotzschiana Müll. Arg. The submontane type accompanies the slope of Serra Geral, in every portion west of the Caí river to the Jaguari region, occurring between 30 and $400 \mathrm{~m}$ above sea level, where the species are adapted to the subtropical climate. And the montane, it gathers species adapted to the accentuated seasonality, in the altitudes between $400 \mathrm{~m}$ and $600 \mathrm{~m}$. Above 600 $\mathrm{m}$, in the RS, the Mixed Ombrophylous Forest occurs (IBGE, 2012; MARCHIORI, 2002).

Phytosociology is an important resource to verify the conservation of ecosystems and to base diagnoses of the sustainability of anthropic activities. Its application can base recovery and management plans. The objective of this review is to compile the results of floristic and phytosociological studies of the SDF arboreal stratum of Serra Geral of RS, in order to elaborate a general characterization of this vegetation (typical species and medium phytosociological and diversity indexes), aiming to obtain an average parameter for comparison in future studies; besides explaining which regions and formations are the most studied and which need more studies.

\section{Material and methods}

In order to search for bibliographical sources, we consulted the portals of CAPES / MEC, SciELO and Google Academic journals, using the following keywords separately: 1) "fitossociologia rio grande do sul"; 2) "phytosociology rio grande do sul"; 3) "florística rio grande do sul"; 4) "floristic rio grande do sul"; 5) "floresta estacional decidual rio grande do sul" and 6) "seasonal deciduous forest rio grande do sul". Only the first 300 entries were selected, if there were more results than this cut-off point. Of these entries, only books, monographs, dissertations, thesis, scientific notes and complete articles were chosen, free and available online. After that, a summary of these works was verified, in order to determine which were related to

Figure 1 - Query results in the Portals of Periodicals by portal and by keyword, quantities of selected studies, as well as the aggregation after the exclusion of duplicates

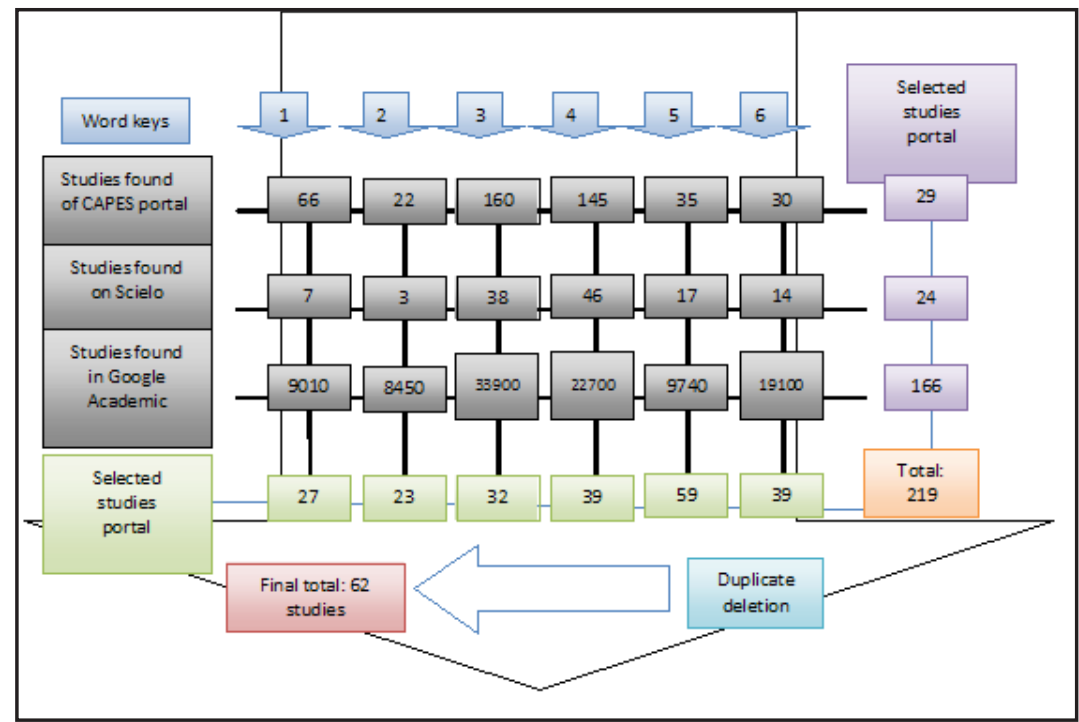

Source: CAPES / MEC (2016), FAPESP; CNPQ; BIREME / PAHO / WHO; FAPUNIFESP (2016) and Google (2016) 
the floristic and phytosociology of the arboreal stratum of the SDF in RS. Then, the works related to the SDF of Alto Uruguay were excluded, separating only those of the from Serra Geral, by comparing the cited coordinates of the study area with the shape of the Decidual Seasonal Forest in RS, a file available in FEPAM (2016).

The total of preselected results was 219 studies (Figure 1). However, 62 studies (50 papers, 5 thesis, 6 dissertations and 1 report) were selected, of which 44 were phytosociological, 15 floristic only and three, phenology. In the results there were also citations for a book, which was added in this review (SCHUMACHER et al., 2011a), of which six articles are on the screen. In addition, the master's dissertation of the first author (ZERWES, 2016), whose chapter 2 is the basis for the present article, was added; as well as the Final Report of the Continuous Forest Inventory (BRENA, 2001).

For the calculation of the medians, standard deviation and amplitudes of the data we used BioEstat 5.3 software (AYRES et al., 2007). Only the studies of the adult arboreal stratum that had an explicit sample adequacy evaluation in the text or sample area equal or superior to $10,000 \mathrm{~m}^{2}$ were considered according to Kersten and Galvão (2011). This area would be close to the minimum for adequate sampling of a tropical forest. Of the variables by type of formation (alluvial, submontane, montane and transitions), studies that did not present the data separated by formations, or that did not mention the altitudes of the sample areas, were disregarded. In the case of studies presenting data already published in an earlier study, the original data were chosen. In this selection, only 37 articles with 73 sample areas remained. In the same software, normality was assessed by the D'Agostino test ( $k$ samples), and the formations were compared by Kruskal-Wallis tests combined or not with the Dunn (non-parametric) or ANOVA (parametric) test.

\section{Results and discussion}

\subsection{Municipalities studied}

In the SDF of the slope of the Serra Geral do RS, studies of the tree stratum are distributed along 29 municipalities (Figure 2). Santa Maria is the municipality with the highest concentration of studies (20), followed by Santa Tereza (seven), Cachoeira do Sul (five), São Martinho da Serra (four), three municipalities with three studies each, five municipalities with two studies each and 17 with one study each. Based on Figure 2, it can be seen that the regions of the Caí river basin, the Antas river valley, slope north of Agudo (high Jacuí river basin), a region between Estrela and Santa Cruz do Sul (Forqueta river basin and Venâncio Aires) and the region between Jaguari and Santa Maria (Ibicuí-Mirim river basin) still lack studies.

Figure 2 - Map of the distribution of phytosociological and floristic studies of the Decidual Seasonal Forest (SDF) of the Serra Geral Slope in RS by municipality. Drawing: Cristian Mateus Zerwes

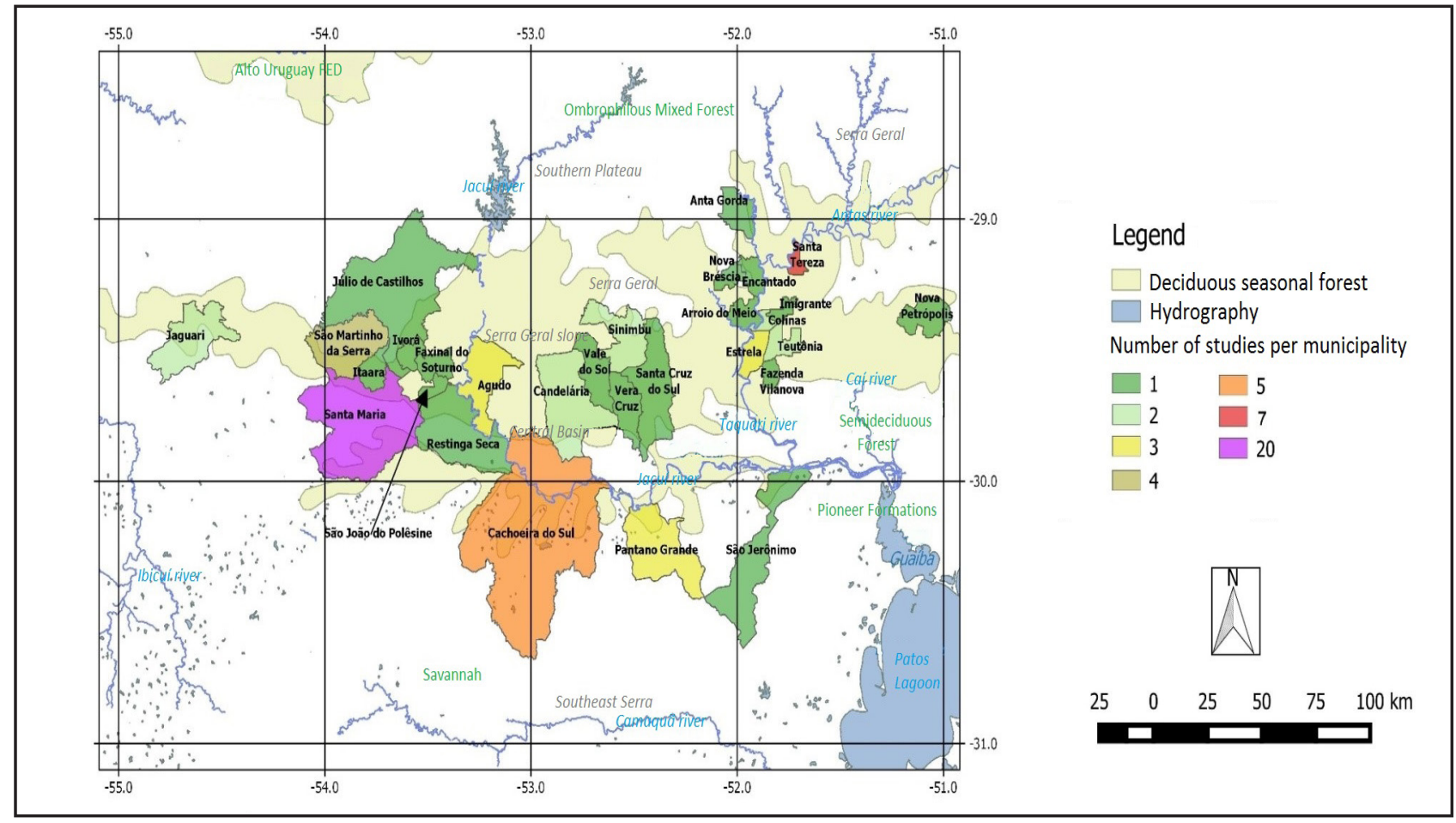

Source: FEPAM (2016) and study data 


\subsection{Methods and inclusion criteria}

Sampling methods and inclusion criteria for height (h), diameter at breast height (DAP) or breast height perimeter (PAP), are diverse for both the adult tree stratum (Table 1) and for the natural regeneration (Figure 3). Three floristic studies use the walking method, however, each with different inclusion criteria or with no defined criterion (all existing individuals being sampled). For phytosociology, 27 studies use the square plots method of $100 \mathrm{~m}^{2}$, but also with different inclusion criteria. The 10 by $20 \mathrm{~m}$ plots are used in ten studies. As different methods, eight other studies use plots of varying sizes $\left(500 \mathrm{~m}^{2}, 2\right.$ by 20 , 12 by 12,15 by 50 and 10 by $100 \mathrm{~m}$ ), two use quadrants, one uses transects, one uses tracks along a trail and other individual census. In natural regeneration studies, circular samples of varying sizes predominate. In view of the above, it is noticed that there is no standardization between studies, especially those of natural regeneration. This fact may hinder the comparison of certain parameters between the studies (JARENKOW, WAECHTER, 2001).

Table 1 - Relationship of studies performed in the adult arboreal stratum of the Seasonal Decidual Forest (SDF) of Serra Geral slope of Rio Grande do Sul, classified according to the methodology of the survey and the inclusion criteria of individuals

\begin{tabular}{|c|c|c|c|c|}
\hline $\begin{array}{l}\text { Criteria for } \\
\text { inclusion }\end{array}$ & Plots 10 by $10 \mathrm{~m}$ & Plots 10 por $20 \mathrm{~m}$ & Plots of other sizes & Other methods \\
\hline $\mathrm{DAP} \geq 4.8 \mathrm{~cm}$ & $\begin{array}{c}\text { Sühs, Putzke and Budke (2010), Sühs } \\
\text { and Budke (2011) }\end{array}$ & - & - & $\begin{array}{l}\text { Walking: Sühs, Putzke and Budke } \\
(2010)\end{array}$ \\
\hline $\mathrm{DAP} \geq 5 \mathrm{~cm}$ & $\begin{array}{c}\text { Budke et al. (2004; 2005), Callegaro } \\
\text { et al. (2012), Scipioni (2012), Scipioni } \\
\text { et al. (2012), Scipioni, Galvão and } \\
\text { Longhi (2013), Callegaro, Araújo and } \\
\text { Longhi (2014) }\end{array}$ & - & $\begin{array}{c}500 \mathrm{~m}^{2}: \\
\text { Scipioni et al. (2015) }\end{array}$ & $\begin{array}{l}\text { Centered quadrants: Milanesi and Leite } \\
\text { (2014). Walking: Grings and Brack } \\
\text { (2009) but } \mathrm{h}>4 \mathrm{~m} \text {. }\end{array}$ \\
\hline $\begin{array}{l}\mathrm{DAP} \geq 5 \mathrm{~cm} \\
\text { and } \mathrm{h} \geq 5 \mathrm{~m}\end{array}$ & Jarenkow and Waechter (2001) & - & - & - \\
\hline $\mathrm{DAP} \geq 8 \mathrm{~cm}$ & - & $\begin{array}{c}\text { Mundeleski, Schmitz and } \\
\text { Biondo (2008) }\end{array}$ & - & - \\
\hline $\mathrm{DAP}>10 \mathrm{~cm}$ & Kilka and Longhi (2011a) & - & - & $\begin{array}{l}\text { Range of } 5 \mathrm{~m} \text { along trail: Alberti, } \\
\text { Longhi and Morellato (2011) }\end{array}$ \\
\hline $\mathrm{h} \geq 3 \mathrm{~m}$ & - & - & - & Walking: Brackmann and Freitas (2013) \\
\hline $\mathrm{PAP} \geq 10 \mathrm{~cm}$ & $\begin{array}{c}\text { Brun, Schumacher and Corrêa (2011), } \\
\text { Bianchin and Bellé (2013) }\end{array}$ & $\begin{array}{l}\text { Vaccaro (1997; 2012), Vacca- } \\
\text { ro, Longhi and Brena (1999), } \\
\text { Kilka and Longhi (2011b) }\end{array}$ & $\begin{array}{l}\quad 2 \text { per } 20 \mathrm{~m}: \\
\text { Andreis et al. (2005) }\end{array}$ & $\begin{array}{c}\text { Transections } 300 \text { meters by } 6 \mathrm{~m} \text { : } \\
\text { Athayde et al. (2009) }\end{array}$ \\
\hline $\mathrm{PAP} \geq 15 \mathrm{~cm}$ & $\begin{array}{c}\text { Brena (2001) only for initial stage, } \\
\text { Araújo (2002), Araújo et al. (2004), } \\
\text { Budke, Jarenkow and Oliveira-Filho } \\
\text { (2006), Lindenmaier and Budke } \\
\text { (2006), Budke (2007), Giehl et al. } \\
\text { (2007), Giehl, Budke and Athayde } \\
\text { (2007), Melo, Putzke and Putzke } \\
\text { (2014) and Zerwes (2016) }\end{array}$ & $\begin{array}{c}\text { Longhi et al. (1999), } \\
\text { Marcuzzo, Araújo and } \\
\text { Longhi (2013), Marcuzzo } \\
\text { et al. (2014) }\end{array}$ & $\begin{array}{l}12 \text { per } 12 \mathrm{~m}: \\
\text { Markus (2014) }\end{array}$ & $\begin{array}{c}\text { Individual census: Naujorks, Laindorf } \\
\text { and Putzke (2015) }\end{array}$ \\
\hline $\mathrm{PAP} \geq 15.7 \mathrm{~cm}$ & - & Dullius (2012) & - & - \\
\hline $\mathrm{PAP} \geq 20 \mathrm{~cm}$ & Teixeira et al. (2014) & - & - & - \\
\hline $\mathrm{PAP} \geq 30 \mathrm{~cm}$ & $\begin{array}{l}\text { Machado and Longhi (1990), Brena } \\
\text { (2001) for medium and advanced } \\
\text { stages, Almeida (2010) and Sccoti } \\
\text { (2012) }\end{array}$ & Longhi et al. (2000) & $\begin{array}{c}15 \text { per } 50 \mathrm{~m}: \\
\text { Farias et al. }(1994) . \\
10 \text { per } 100 \mathrm{~m}: \\
\text { Hack et al. }(2005) . \\
20 \text { per } 20 \mathrm{~m}: \\
\text { Scipioni et al. }(2010 ; 2011)\end{array}$ & - \\
\hline $\mathrm{PAP} \geq 35 \mathrm{~cm}$ & - & - & $\begin{array}{l}15 \text { per } 50 \mathrm{~m} \text { : Glufke et al. } \\
(1994)\end{array}$ & - \\
\hline $\begin{array}{l}\text { No defined } \\
\text { criteria }\end{array}$ & Rovedder et al. (2014) & - & - & $\begin{array}{l}\text { Centered quadrants: Garcia et al. } \\
\text { (2013). Route: Bueno et al. (1987); } \\
\text { Tabarelli (1992); Spellmeier (2008); } \\
\text { Spellmeier, Périco and Freitas (2009). }\end{array}$ \\
\hline
\end{tabular}

${ }^{1}$ Subplots of 10 by $10 \mathrm{~m}$, within plots of 20 by $20 \mathrm{~m}$

Legend: DAP - diameter at breast height; $\mathrm{h}$ - height; PAP - perimeter at breast height.

Source: study data 1 . 
Figure 3 - Classification table in the different methods and inclusion criteria used by the natural regeneration studies of the SDF of Serra Geral slope from Rio Grande do Sul

\begin{tabular}{|c|c|c|c|c|}
\hline \multirow{3}{*}{$\begin{array}{c}\text { Circles } \mathbf{1 0} \mathbf{~ m}^{\mathbf{2}} \text { : } \\
\text { - PAP }<\mathbf{1 5} \mathbf{~ c m}-\text { Farias et al. } \\
(1994) \\
\text { - PAP } \leq \mathbf{1 5} \mathbf{~ c m}-\text { Machado } \\
\text { and Longhi (1990); } \\
\text { - PAP }<\mathbf{1 5} \text { cm and } \mathbf{h} \geq \mathbf{0 , 3} \mathbf{~ m} \\
\text {-Marcuzzo, Araújo and Longhi } \\
\text { (2013), Marcuzzo et al. (2014). }\end{array}$} & $\begin{array}{c}\text { Circles } \mathbf{2 5} \mathbf{~ m}^{\mathbf{2}}: \\
\bullet \mathbf{h} \leq \mathbf{0 , 3} \mathbf{~ m} \\
- \text { Andrae et al. }(2005) . \\
\text { Plots } \mathbf{1} \text { x } \mathbf{4} \mathbf{~ m : ~} \\
\text { PAP }<\mathbf{1 5} \mathbf{~ c m} \text { and } \mathbf{h} \geq \mathbf{0 , 2} \mathbf{~ m} \\
- \text { Araújo }(2002) .\end{array}$ & \multirow{3}{*}{ 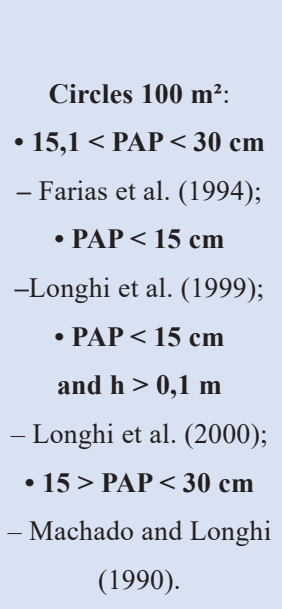 } & \multirow{3}{*}{ 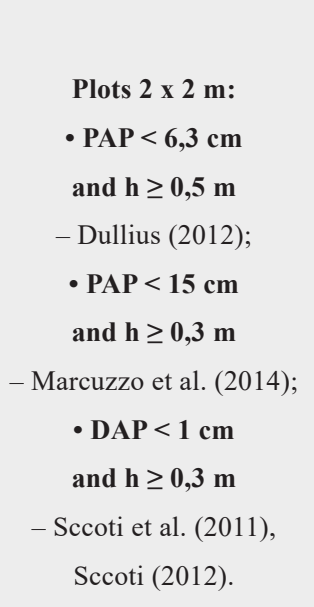 } & $\begin{array}{c}\text { Plots } \mathbf{5} \text { x } \mathbf{5} \text { m: } \\
\cdot \mathbf{3 , 1 4} \leq \mathbf{P A P}<\mathbf{1 5} \mathbf{~ c m} \\
\text { - Sccoti et al. }(2011), \\
\text { Sccoti }(2012) ; \\
\cdot \mathbf{6 , 3}<\mathbf{P A P}<\mathbf{1 5 , 7} \mathbf{~ c m} \\
\text { - Dullius (2012). } \\
\end{array}$ \\
\hline & $\begin{array}{c}\text { Plots } 2 \text { x } \mathbf{1} \text { m: } \\
\bullet \quad \mathbf{0 , 1}<\mathbf{h}<\mathbf{1} \mathbf{~ m} \\
- \text { Kilka and Longhi }(2011 \mathrm{~b}) \text {. }\end{array}$ & & & Plots $10 \times 10 \mathrm{~m}$ : \\
\hline & 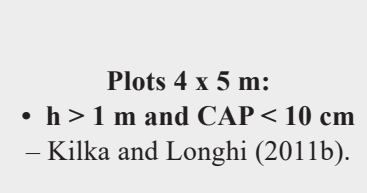 & & & $\begin{array}{c}\bullet \mathbf{5}<\text { PAP }<\mathbf{3 0} \mathbf{c m} \\
\text { - Scipioni et al. (2008); } \\
\boldsymbol{\bullet} \mathbf{1 5}<\text { PAP }<\mathbf{3 0} \mathbf{c m} \\
\text { - Almeida }(2010) .\end{array}$ \\
\hline
\end{tabular}

Source: data from the study

\subsection{Formations studied}

Of the 62 studies, seven deal exclusively in alluvial formation, 41 exclusively in the submontane formation, and four exclusively in montane formation. Three studies contemplate areas in alluvial and submontane formation and their transition; three contemplate, in their surveys, sub-montane and montane formations; two others contemplate all three formations; end yet, there are two studies that contemplate the transition of the montane formation with the Mixed Ombrophilous Forest. Considering the aspect of SDF marginal areas, the use of information from nearby areas, especially the Mixed Ombrophylous Forest (such as the areas in the municipalities of Anta Gorda, Júlio de Castilhos, Nova Brescia, Nova Petrópolis, São Martinho da Serra, Santa Tereza and Sinimbu) and the contacts with the Pampa Biome (Cachoeira do Sul, Fazenda Vilanova, Jaguari, Pantano Grande, São Jerônimo and Santa Maria), may affect the inclusion of characteristics that are not the same as the SDF core. However, this separation is not the focus of the present study, which would require a multivariate analysis of the floristic, phenology, diversity and phytosociology data of all the studied areas, in order to separate the possible groups. It is also worth mentioning that we compared the classification of the authors of each study with the SDF shape file available in FEPAM (2016) using software Quantum GIS, so as not to include studies that would be outside SDF.

\subsection{Objectives and themes}

The objectives and themes of the 62 studies selected, range from descriptions of floristic composition to multivariate grouping analyzes and their relationships with environmental and physical disturbances, or vegetation dynamics, which highlights the importance of phytosociology in understanding the dynamics of plant populations and their relationship with biotic and abiotic factors. Papers focusing exclusively on floristics are produced by Bueno et al. (1987), Tabarelli (1992), Markus and Freitas (2011), Brackmann and Freitas (2013) and Melo, Putzke and Putzke (2014). Grings and Brack (2009) also raise floristics, however, throughout the municipality of Nova Petrópolis. In turn, phenology is the theme of Andreis et al. (2005), Athayde et al. (2009) and Alberti, Longhi and Morellato (2011). Meanwhile, the spectra of the different diaspore dispersion strategies are characterized by Giehl et al. (2007) on a slope and by Budke et al. (2005) in riparian forest.

Machado and Longhi (1990) on a hill, Farias et al. (1994) in military area, Longhi et al. (1999) and Hack et al. (2005) on rural properties, Longhi et al. (2000) in an association, Jarenkow and Waechter (2001) on a slope; Budke et al. (2004), Lindenmaier and Budke (2006), Callegaro et al. (2012), Milanesi and Leite (2014), Teixeira et al. (2014) and Naujorks, Laindorf and Putzke (2015) in ciliary forest, Sühs, Putzke and Budke (2010) and Sühs and Budke (2011) in conservation unit, Bianchin and Bellé (2013) in alluvial formation and Garcia et al. (2013) in a training center, aim to characterize the composition, structure and phytosociology of the arboreal stratum. Mundeleski, Schmitz and Biondo (2008), as well as floristic and phytosociology, also size the infestation of Hovenia dulcis Thunb. in riparian forest.

The quantitative-qualitative evaluation of forest resources is the objective of Brena (2001), while Glufke et al. (1994) analyze the production of a natural SDF in Santa Maria (commercial volume and wood quality). The forest fragments in dairy farms and their relation with the sustainability of the activity are the themes of Markus (2014) specifically in permanent preservation 
areas (APP), and of Zerwes (2016), in the APP and areas proposed for legal reserve. Spellmeier (2008) and Spellmeier, Périco and Freitas (2009) study the effect of grazing on vegetation.

Sccoti et al. (2011) and Sccoti (2012) work with the analysis of vegetation clusters and their dynamics and regeneration potential, also including analysis of seedling banks, seed bank in the soil and seed rain; which is also the theme of Araújo (2002) and Araújo et al. (2004). The cluster analysis is also used by Callegaro, Araújo and Longhi (2014) in a conservation unit. Vaccaro (1997) and Vaccaro, Longhi and Brena (1999) compare vegetation structure between three successional stages; and the studies by Kilka and Longhi (2011b) and Vaccaro (2012), evaluate the changes in floristic composition and phytosociological structure, the dynamics of entry and increment in basal area and mortality of specimens. In this bias, Marcuzzo et al. (2014) study the evolution of the restoration of degraded areas. Meanwhile, Brun, Schumacher and Corrêa (2011), work with the evaluation of nutrients in biomass above and below the soil of the SDF. And Andrae et al. (2005) focus on the floristic composition in plantation of Pinus spp. and Araucaria angustifolia (Bertol.) Kuntze.

The occurrence of vegetation groupings and the relation with slope, topography and pedology is evaluated by Giehl, Budke and Athayde (2007), Scipioni et al. (2008), Almeida (2010), Scipioni et al. (2008), Dullius (2012), Scipioni (2012), Marcuzzo, Araújo and Longhi (2013), Rovedder et al. (2014) and Almeida et al. (2015). Scipioni, Galvão and Longhi (2013) evaluate the differences of ecological guilds between the clusters. Budke, Jarenkow and Oliveira-Filho (2006) and Budke (2007), besides evaluating topography and pedology, evaluate the influence of flood pulses disturbances on vegetation. Another complex study is that of Kilka and Longhi (2011a), which focuses on the predominant taxonomic groups and floristic similarity between several areas along the Serra Geral slope and the potential use of each species.

\subsection{Diversity and Phytosociology}

The species richness of the SDF of the Serra Geral Slope (without considering natural regeneration), in 37 studies that present a sample intensity calculation, has a median of 54 species $(\sigma=33.7)$. The amplitude is of 217, with only six tree species (SPELLMEIER, 2008) and up to 223 in the Forest Inventory of Rio Grande do Sul (BRENA, 2001), however, also considering the SDF of Alto Uruguay; and the maximum for only from the SDF of the Serra Geral Slope is 160 species (SÜHS; PUTZKE; BUDKE, 2010).

In alluvial formations, the median richness becomes $36(\sigma=13.7)$, with an amplitude of 43 (minimum $=6$ ). In the transition between alluvial and submontane formations, in the only study (SCIPIONI, 2012), the richness was 90 species. In the submontane, the median is $54(\sigma=22.3)$, with amplitude of 106 (minimum $=24)$. In the transition between submontane and montane, the median is $68.5(\sigma=17.1)$, with an amplitude of 41 (minimum $=43)$. And on the montane, the median is $56(\sigma=$ 38 ), with amplitude of 117 (minimum $=43$ ). Alluvial formation has a significantly lower richness compared to submontane, montane and submontane / montane formations (Kruskal-Wallis $\mathrm{H}=12.8238$; gl $=3$; $\mathrm{p}=0.005$; Dunn $\mathrm{p}<0.05$ ). This lower abundance of alluvial formation may be associated with frequent flooding and hydromorphic soil, which, according to Scipioni (2012), leads to greater ecological dominance of species adapted to this environment, such as G. klotzschiana.

It should be noted that different sampling methods may, however, reflect differences in richness. Therefore, in formations with few studies (transitions between alluvial / submontane and submontane / montane), it is recommended to evaluate the methods used before comparing them.

As for the most representative families, Fabaceae is the richest in 55.2\% of the areas surveyed (73), with up to 16 species in a single survey. According to Jarenkow and Waechter (2001), there is a predominance of species of Fabaceae in the seasonal forests that come from the migration corridor of the Paraná and Uruguay river basins, and its success is possibly due to the association of nitrogen-fixing bacteria in their roots. Myrtaceae is the richest family in $41.4 \%$ of the studies, with up to 18 species in a single study. This family include species that occupy the canopy or understory and are widely distributed in the RS or from the Atlantic contingent (GRINGS; BRACK, 2009). Lauraceae is the richest in 1.7\% of the studies, with up to eight species; and Euphorbiaceae is the richest, too, in $1.7 \%$ of the studies, with up to nine species.

The richest genus in $83.7 \%$ of the studies (considering only those with more than three species per genus) is Eugenia, with up to nine species in a single study; this genus of Myrtaceae has wide distribution and richness in the state of RS (JARENKOW; WAECHTER, 2001). Other genera with relevant richness are Myrsine (up to six species in a single study), as well as Ocotea and Zanthoxylum (four each).

Among the species with the highest indexes of importance (IVI), the following stand out in 41 sample areas: A. concolor (highest IVI in nine areas), Cupania vernalis Cambess. (Nine), Nectandra megapotamica (Spreng.) Mez (five), G. klotzschiana (four), L. divaricata (three), Allophylus edulis (A. St.-Hil., Cambes. \& A. Juss.) Radlk. and Lithrea molleoides (Vell.) Engl. (two each); as well as Casearia sylvestris Sw., Eugenia ramboi D. Legrand, Helietta apiculata Benth., Machaerium paraguariense Hassl., M. frondosus, Trichilia clausseni C. DC. and Trichilia elegans (one each).

A. concolor is a dominant species in the understory, which means that it has a high density and frequency in several studies (JARENKOW; WAECHTER, 2001; SCIPIONI, 2012), thus raising its IVI. T. elegans is also a species of understory. A. edulis, $C$. sylvestris and $C$. vernalis stand out in secondary forests because they are light demanding species, whereas $E$. ramboi, $L$. divaricata and $N$. megapotamica are common species with great dominance in the canopy of secondary and primary forests (GLUFKE et al., 1994; GRINGS; BRACK, 2009). G. klotzschiana presents high IVI in alluvial and/or riverine forests, where 
Figure 4 - Graph showing the amplitude of the richness of species by formations of the Seasonal Decidual Forest (SDF) of the Serra Geral Slope of Rio Grande do Sul

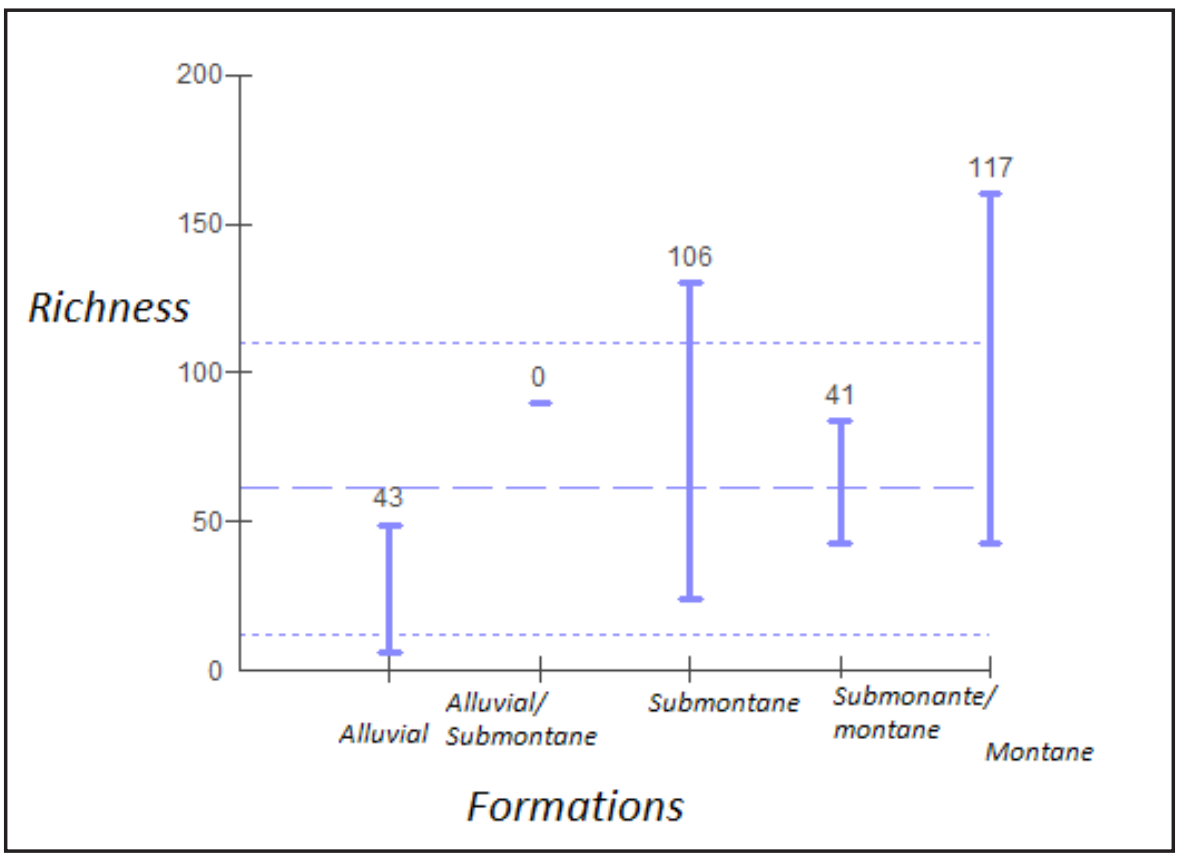

Legend: bars - amplitude of species richness by formation; Dotted lines - standard deviation; Dashed line - overall mean. Source: study data

it adapts to the hydromorphic environment (BUDKE, 2007), as well as M. paraguariense (TEIXEIRA et al., 2014). L. molleoidesis a more common species at the west end of the SDF, being an pioneer (DULLIUS, 2012). H. apiculata has high densities in the western half of the SDF (LONGHI et al., 1999). M. frondosus, although threatened with extinction, may form clusters, such as that recorded by Longhi et al. (2000) and T. clausseni, is associated to the mature forest, usually occurring on slopes with rocky outcrops (KILKA; LONGHI, 2011b).

About invasion of exotic species, it is diagnosed in 31 of the 73 sampled areas, with an average of 4.3 or median of two exotic species per area. The greatest richness of exotic species (22) is recorded by Zerwes (2016) on dairy farms. However, 12 studies have sampled only one exotic species. The species that generate the greatest concern are the invaders H. dulcis and Tecoma stans (L.) Juss. ex Kunth, who have eradication policies due to their infestation in certain areas of the SDF of Serra Geral (MUNDELESKI; SCHMITZ; BIONDO, 2008; ZERWES, 2016).

Only 13 studies present the evaluation of the species distribution per migratory contingent, where in eight the species of wide distribution in the RS obtains the greatest species richness, while in the other five, the greatest richness is in the species of the western contingent (Paraná- Uruguay river basins). The distribution of migratory contingents by density of individuals is measured in ten studies, where eight show greater species richness in the wide distribution in the RS contingent, and two in the western contingent. Thus, the SDF of the Serra Geral Slope tends to have larger participation of species of wide distribution in RS, followed by the western contingent, while the other contingents make a small contribution.

As for the propagation syndromes of propagules, twelve studies evaluate the distribution by the species richness, where all obtain greater number of zoochoric species. While in the distribution by density of individuals, of the ten studies, eight presented higher density of zoochory and two, autochory. Budke et al. (2005) emphasize the important contribution of biotic agents in the dispersal of propagules in forests, but the autochory, presents a considerable contribution in terms of density in the forest, due to the large number of individuals in the underwood such as A. concolor or typical of riparian environments as G. klotzschiana.

In the question of ecological groups of succession, 18 studies present the distribution by species richness and by density. In richness, the group of light-demanding species for its development (or even light-demanding or early secondary climaxes) is the richest in 15 studies, followed by species called plastic (or adaptable to various environments) in two studies, and understory species in one study. By individuals, the group of light-demanding has the highest number of specimens in only five studies; while the shadow tolerant (or late secondary) are the most abundant in nine studies. The understory group is the most abundant in three studies and the pioneers in a single study. According to Scipioni (2012) and Vaccaro (2012), a more advanced forest tends to have larger proportions of late secondary and understory species, whereas earlier stages tend to have higher proportions of pioneer and early secondary species; from the evaluation of these proportions it's possible infer the degree of ecological succession of the forest. The diversity and the equability of the arboreal stratum species of the Serra Geral Slope (without considering natural regeneration), respectively, through the indexes of Shannon-Wiener (H') and Pielou (E'), has a 
median of 3.10 and $0.78(\sigma=0.60$ and 0.13$)$ and amplitude of 2.42 and 0.38 . The lowest $H^{\prime}$ is 1.3946 , in the early secondary vegetation of the Continuous Forest Inventory (BRENA, 2001) and the highest, of 3.81 nats, in APP of dairy farms (ZERWES, 2016); and the lowest E' is 0.46 in Cachoeira do Sul (ALMEIDA, 2010) and the largest is 0.844 in Santa Maria (SCCOTI, 2012). The amplitude of H' by formations is shown in Figure 5.

Figure 5 - Graph showing the amplitude of the diversity of Shannon (H') in nats, by formations of Seasonal Decidual Forest (SDF) of Serra Geral slope, Rio Grande do Sul

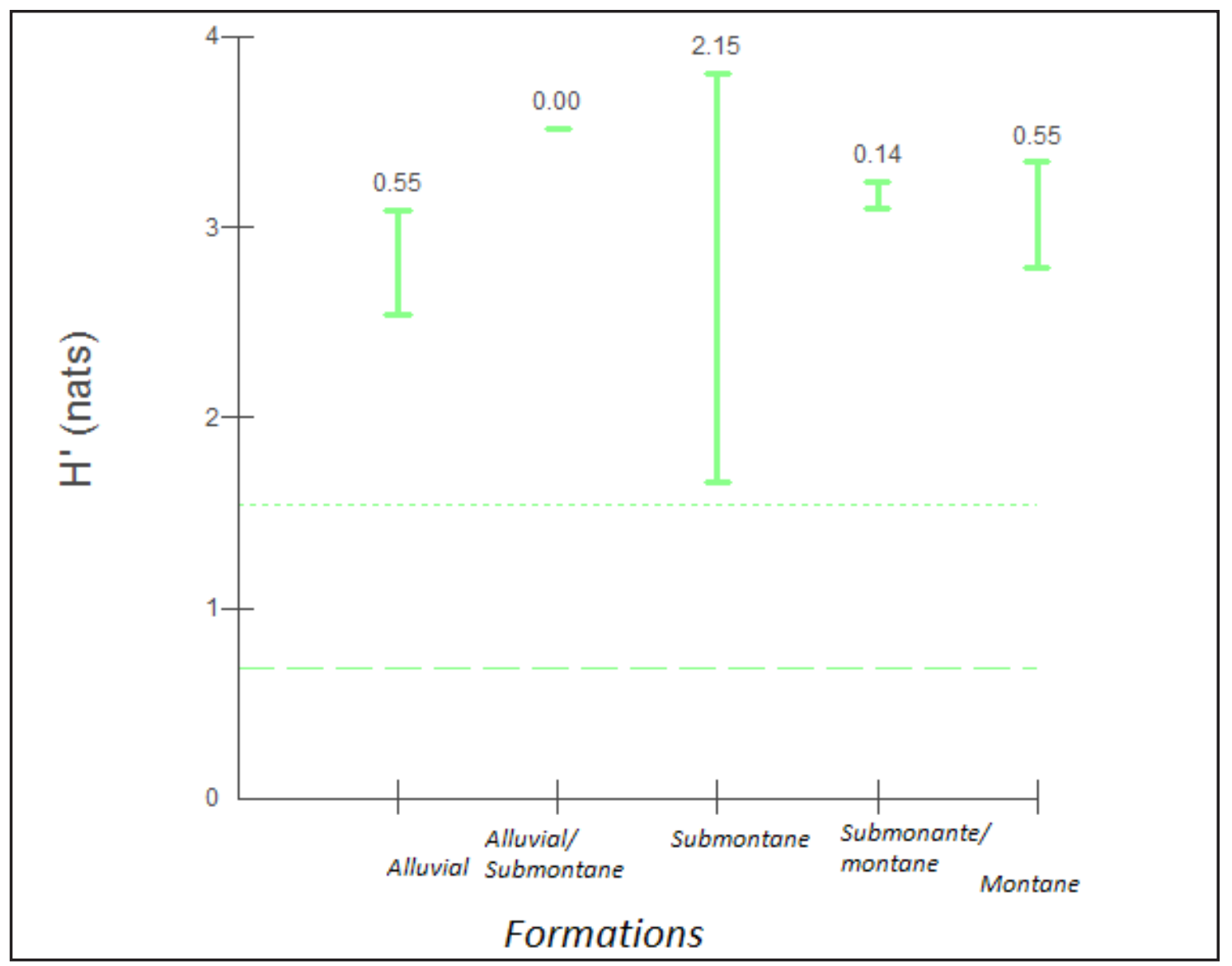

Legend: Bars - amplitude of Shannon diversity by formation; Dotted line - standard deviation; Dashed line - average

In alluvial formations, the median H' and E', respectively, become 2.82 and $0.81(\sigma=0.24$ and 0.03$)$, with amplitude of 0.55 and 0.06 (minimum $=2.54$ and 0.78 ). In alluvial to submontane transition, $H^{\prime}$ and $E^{\prime}$, respectively, are 3.52 and 0.77 . In sub-montane formations, the median H' and E', respectively, are 3.21 and $0.78(\sigma=0.66$ and 0.14$)$, with amplitude of 2.15 and 0.38 (minimum $=1.66$ and 0.46 ). In the transition from submontane to montane, the median $H^{\prime}$ and E', respectively, are 3.17 and $0.80(\sigma=0.10$ and 0.04$)$, with amplitude of 0.14 and 0.05 (minimum $=3.10$ and 0.77 ). In montane formations, the median H' and E', respectively, have the values of 3.12 and $0.79(\sigma=0.24$ and 0$)$, with amplitude of 0.55 and 0 (minimum $=2.789$ and 0.79$)$. There was no significant difference in $H^{\prime}($ ANOVA F $=0.2523, \mathrm{p}=0.9065)$ and E' $($ Kruskal-Wallis $\mathrm{H}=$ $1.5727, \mathrm{gl}=2, \mathrm{p}=0.4555)$ among the environments. However, as in the richness, it should be emphasized that the different sampling methods may end up reflecting differences in the indexes.

About the density, this value is very variable (median $=1478.9$ ind.ha ${ }^{-1}, \sigma=977.9$ ), since the different inclusion criteria generate considerable changes in the number of individuals per hectare. Thus, the ideal is only to make comparisons between studies with the same inclusion criteria: DAP $\geq 5 \mathrm{~cm}\left(\right.$ median $=2052$ ind. $\left.\mathrm{ha}^{-1} ; \sigma=128.1\right)$, DAP $\geq 10 \mathrm{~cm}($ median $=754$ ind. ha $\left.^{-1} ; \sigma=133,3\right)$, PAP $\geq 15 \mathrm{~cm}\left(\right.$ median $=1622.9$ ind.ha $\left.^{-1} ; \sigma=332\right)$, PAP $\geq 10 \mathrm{~cm}\left(\right.$ median $=3722.5$ ind ha $\left.{ }^{-1}, \sigma=1091.5\right)$, PAP $>20 \mathrm{~cm}\left(2305.56\right.$ ind $\left.\cdot \mathrm{ha}^{-1}\right)$, PAP $\geq 30 \mathrm{~cm}($ median $=504)$, PAP between 15 and $30 \mathrm{~cm}\left(\right.$ median $=1039$ ind ha $\left.^{-1} ; \sigma=168.4\right)$ and PAP between 5 and $30 \mathrm{~cm}\left(2485\right.$ ind.ha $\left.{ }^{-1}\right)$.

As for dendrometry, considering all the forest strata (understory, medium stratum, canopy and emergent), the median DAP is $12.4 \mathrm{~cm}(\sigma=5.0)$ and the height is $8.8 \mathrm{~m}(\sigma=2.4)$. These values are below the average for the state of RS and the result obtained by the Continuous Forest Inventory for the SDF itself (BRENA, 2001). However, due to the different criteria for inclusion of individuals (DAP or minimal PAP), these variables can change considerably. 
In summary, SDF studies of Serra Geral Slope focus on the Santa Maria region and valleys of the Pardo and Taquari river basins, while regions such as the valleys of high Jacuí, Antas, Caí, Forqueta and Ibicuí-Mirim rivers, and surrounding Venâncio Aires are subsampled. The median richness is 54 species, however, the alluvial formation presents significantly lower richness than the other formations. Fabaceae is generally the richest family, while Eugenia spp. is the richest genre. Species that present, in several studies, the higher IVI, are A. concolor and C. vernalis. The species of wide distribution in the RS and zoochory tend to have important participations in the richness and density of the SDF of the Serra Geral Slope. As for the guilds of ecological succession, the early secondary have important participation in the species richness and the later secondary in its turn in the density. The median diversity index of Shannon is 3.10 and Pielou equability is 0.78 , with no significant differences between formations. The different sampling methods and inclusion criteria of DAP have repercussions on variable results in density, height and DAP, creating obstacles to the comparison.

\section{Conclusions}

There are several floristic and phytosociological studies carried out in the SDF of the Serra Geral Slope of Rio Grande do Sul State, Brazil, considering both conserved and regenerated environments due to natural phenomena (flood pulses) or anthropogenic impacting actions. A wide range of information on the tree stratum is already available, especially in relation to the riparian forest and submontane formation. These data are essential for future studies and projects in the region, as they can be compared to diagnose environmental conservation and support interventions for the recovery of degraded areas and sustainable management projects.

On the other hand, we highlight the lack of studies in certain formations, suggesting that future studies focus on montane formations and alluvial / submontane, submontane / montane and SDF / mixed ombrophilous forests transition. As well as in the regions with few studies mentioned above, with special focus on the inlet valleys of the Caí, Antas and Forqueta rivers, and respective tributaries, which present proportionally large remnants and are threatened by hydroelectric projects. Phytosociology is applied to describe the different strata, to discuss changes due to environmental variables (pedology, floods, topography), to calculate wood stock and as a component of sustainability index. However, it should be emphasized that phytosociology should not only be used as a tool for obtaining data, but rather as an important instrument to evaluate the conservation of ecosystems and as a diagnostic of the sustainability of anthropic activities. A suggestion for the continuity of SDF studies would be a multivariate analysis of phenological, floristic, phytosociological and diversity data, based on existing data and new data that may be aggregated, in order to verify the occurrence of different groupings or types of formations within the SDF, such as separation between core areas and marginal or contact areas. Also, the comparison could be extended to include studies in the RS Semi-deciduous Seasonal Forest, in order to follow the idea of Schumacher et al. (2011b).

\section{References}

ALBERTI, Luis Fernando; LONGHI, Solon Jonas; MORELATTO, L. Patrícia. Padrão fenológico de árvores e a relação com o clima. In: SCHUMACHER, Mauro Valdir et al. A floresta estacional subtropical: caracterização e ecologia no rebordo do Planalto Meridional. Santa Maria: Pallotti, 2011. Cap. 6. p. 105-120.

ALMEIDA, Clarice Maboni de et al. Análise de agrupamentos em remanescente de floresta estacional decidual. Ciência Florestal, Santa Maria, v. 25, n. 3, p.781-789, 2015.

ALMEIDA, Clarice Maboni de. Relação solo-fitossociologia em um remanescente de floresta estacional decidual. 2010.74 f. Dissertação (Mestrado) - Curso de Pós-graduação em Engenharia Florestal, Centro de Ciências Rurais, Universidade Federal de Santa Maria, Santa Maria, 2010.

ANDRAE, Franz H. et al. Sub-bosque de reflorestamentos de Pinus em sítios degradados da região da floresta estacional decidual do Rio Grande do Sul. Ciência Florestal, Santa Maria, v. 15, n. 1, p.43-63, 2005.

ANDREIS, Cáren et al. Estudo fenológico em três fases sucessionais de uma floresta estacional decidual no município de Santa Tereza, RS, Brasil. Árvore, Viçosa, v. 29, n. 1, p.55-63, 2005.

ARAÚJO, Maristela Machado et al. Análise de agrupamento da vegetação de um fragmento de floresta estacional decidual aluvial, Cachoeira do Sul, RS, Brasil. Ciência Florestal, Santa Maria, v. 14, n. 1, p.133-147, 2004. 
ARAÚJO, Maristela Machado. Vegetação e mecanismos de regeneração em fragmento de floresta estacional decidual ripária, Cachoeira do Sul, RS, Brasil. 2002. 172 f. Tese (Doutorado) - Curso de Pós-graduação em Engenharia Florestal, Centro de Ciência Rurais, Universidade Federal de Santa Maria, Santa Maria, 2002.

ATHAYDE, Eduardo Anversa et al. Fenologia de espécies arbóreas em uma floresta ribeirinha em Santa Maria, sul do Brasil. Revista Brasileira de Biociências, Porto Alegre, v. 7, n. 1, p.43-51, 2009.

AYRES, Manuel et al. BioEstat: aplicações estatísticas nas áreas das ciências bio-médicas. 5. ed. Belém: 2007.380 p.

BIANCHIN, Jonas Eduardo; BELLÉ, Pierre André. Fitossociologia e estrutura de um fragmento de Floresta Estacional Decidual Aluvial em Santa Maria - RS. Agroambiente On-line, Boa Vista, v. 7, n. 3, p.322-330, 2013.

BRACKMANN, Cátia Eloísa; FREITAS, Elisete Maria de. Florística arbórea e arbustiva de um fragmento de Mata Ciliar do arroio Boa Vista, Teutônia, RS, Brasil. Hoehnea, São Paulo, v. 40, n. 2, p.365-372, 2013.

BRUN, Eleandro J.; SCHUMACHER, Mauro Valdir; CORRÊA, Robson S. Inventário de biomassa e nutrientes em florestas secundárias de Santa Tereza. In: SCHUMACHER, Mauro Valdir et al. A Floresta Estacional Subtropical: caracterização e ecologia no rebordo do Planalto Meridional. Santa Maria: Pallotti, 2011. Cap. 11. p. 215-237.

BUDKE, Jean Carlos et al. Composição florística e estratégias de dispersão de espécies lenhosas em uma floresta ribeirinha, arroio Passo das Tropas, Santa Maria, RS, Brasil. Iheringia: Série Botânica, Porto Alegre, v. 60, n. 1, p.17-24, 2005.

BUDKE, Jean Carlos et al. Florística e fitossociologia do componente arbóreo de uma floresta ribeirinha, arroio Passo das Tropas, Santa Maria, RS, Brasil. Acta Botanica Brasilica, Belo Horizonte, v. 3, n. 18, p.581-589, 2004.

BUDKE, Jean Carlos. Pulsos de inundação, padrões de diversidade e distribuição de espécies arbóreas em uma floresta ribeirinha no sul do Brasil. 2007. 195 f. Tese (Doutorado) - Curso de Pós-graduação em Botânica, Instituto de Biociências, Universidade Federal do Rio Grande do Sul, Porto Alegre, 2007.

BUDKE, Jean Carlos; JARENKOW, João André; OLIVEIRA-FILHO, Ary Teixeira de. Relationships between tree component structure, topography and soils of a riverside forest, Rio Botucaraí, Southern Brazil. Plant Ecology, Rotterdam, p.1-14, 2006.

BUENO, Olinda Leites. Florística em áreas da margem direita do baixo Jacuí, RS, Brasil. Acta Botanica Brasilica, Belo Horizonte, v. 1, n. 2, p.101-121, 1987.

CALLEGARO, Rafael Marian et al. Estrutura do componente arbóreo de uma floresta estacional decidual ripária em Jaguari, RS. Ciência Rural, Santa Maria, v. 42, n. 2, p.305-311, 2012.

CALlEGARO, Rafael Marian; ARAÚJO, Maristela Machado; LONGHI, Solon Jonas. Fitossociologia de agrupamentos em Floresta Estacional Decidual no Parque Estadual Quarta Colônia, Agudo-RS. Revista Brasileira de Ciências Agrárias: Agrária, Recife, v. 9, n. 4, p.590-598, 2014.

CAPES/MEC. Portal de Periódicos CAPES/MEC. 2016. Disponível em: <http://www.periodicos.capes.gov.br/>. Acesso em: 14 fev. 2016.

CORDEIRO, José Luís Passos; HASENACK, Heinrich. Cobertura vegetal atual do Rio Grande do Sul. In: PILLAR, Valério de Patta et al (Ed.). Campos sulinos: conservação e uso sustentável da biodiversidade. Brasília: Ministério do Meio Ambiente, 2009. Cap. 23. p. 285-299.

DULLIUS, Michelle. Vegetação e solos de uma floresta estacional do Rio Grande do Sul. 2012. 128 f. Dissertação (Mestrado) - Curso de Pós-graduação em Ciência do Solo, Centro de Ciências Rurais, Universidade Federal de Santa Maria, Santa Maria, 2012.

FAPESP; CNPQ; BIREME/OPAS/OMS; FAPUNIFESP. SciELO - Scientific Electronic Library Online. 2016. Disponível em: $<$ http://www.scielo.org/php/index.php>. Acesso em: 14 fev. 2016.

FARIAS, José Antônio Cardoso et al. Estrutura fitossociológica de uma floresta estacional decidual na região de Santa Maria, RS. Ciência Florestal, Santa Maria, v. 4, n. 1, p.109-128, 1994. 
FEPAM. Biblioteca digital: arquivos digitais para uso em SIG - base cartográfica digital do RS 1:250.000. 2016. Disponível em: <http://www.fepam.rs.gov.br/biblioteca/geo/bases_geo.asp>. Acesso em: 19 fev. 2016.

GARCIA, Eduarda Naujorks et al. Levantamento florístico e fitossociológico em área de centro de pesquisa de Santa Cruz do Sul, Rio Grande do Sul, Brasil. Caderno de Pesquisa: série Biologia, Santa Cruz do Sul, v. 25, n. 3, p.6-26, 2013.

GIEHL, Eduardo Luís Hettwer et al. Espectro e distribuição vertical das estratégias de dispersão de diásporos do componente arbóreo em uma floresta estacional no sul do Brasil. Acta Botanica Brasilica, Belo Horizonte, v. 21, n. 1, p.137-145, 2007.

GIEHL, Eduardo Luís Hettwer; BUDKE, Jean Carlos; ATHAYDE, Eduardo Anversa. Distribuição espacial de espécies arbóreas em uma floresta estacional em Santa Maria, sul do Brasil. Pesquisas: Botânica, São Leopoldo, n. 58, p.215-226, 2007.

GLUFKE, Clarice et al. Produção de uma floresta natural em Santa Maria, RS. Ciência Florestal, Santa Maria, v. 4, n. 1, p.61-76, 1994.

GOOGLE. Google Acadêmico. 2016. Disponível em: <https://scholar.google.com.br/>. Acesso em: 14 fev. 2016.

GRINGS, Martin; BRACK, Paulo. Árvores na vegetação nativa de Nova Petrópolis, Rio Grande do Sul. Iheringia: Série Botânica, Porto Alegre, v. 64, n. 1, p.5-22, 2009.

HACK, Cristiano et al. Análise fitossociológica de um fragmento de floresta estacional decidual no município de Jaguari, RS. Ciência Rural, Santa Maria, v. 35, n. 5, p.1083-1091, 2005.

HIROTA, Marcia Makiko; PONZONI, Flávio Jorge (Coord.). Atlas dos remanescentes florestais da mata atlântica período 2012-2013: relatório técnico. São Paulo: Fundação SOS Mata Atlântica, Instituto Nacional de Pesquisas Espaciais - INPE, 2014. $61 \mathrm{p}$.

IBGE. Manual Técnico da Vegetação Brasileira: Sistema fitogeográfico Inventário das formações florestais e campestres Técnicas e manejo de coleções botânicas Procedimentos para mapeamentos. 2. ed. Rio de Janeiro: IBGE, 2012.275 p. (Manuais Técnicos em Geociências).

JARENKOW, João André; WAECHTER, Jorge Luiz. Composição, estrutura e relações florísticas do componente arbóreo de uma floresta estacional no Rio Grande do Sul, Brasil. Revista Brasileira de Botânica, São Paulo, v. 24, n. 3, p.263-272, 2001.

KERSTEN, Rodrigo de Andrade; GALVÃO, Franklin. Suficiência amostral em inventários florísticos e fitossociológicos. In: FELFILI, Jeanine Maria et al. Fitossociologia no Brasil: métodos e estudos de casos. Viçosa: UFV, 2011. Cap. 5. p. 156173. Volume I.

KILCA, Ricardo de Vargas; LONGHI, Solon Jonas. A composição florística e a estrutura das florestas secundárias no rebordo do Planalto Meridional. In: SCHUMACHER, Mauro Valdir et al. A floresta estacional subtropical: caracterização e ecologia no rebordo do Planalto Meridional. Santa Maria: Pallotti, 2011a. Cap. 4. p. 53-84.

KILCA, Ricardo de Vargas; LONGHI, Solon Jonas. A regeneração natural e a sucessão condicionada por diferentes tipos de distúrbios: um estudo de caso. In: SCHUMACHER, Mauro Valdir et al. A floresta estacional subtropical: caracterização e ecologia no rebordo do Planalto Meridional. Santa Maria: Pallotti, 2011b. Cap. 7. p. 121-140.

LEITE, Pedro Furtado; KLEIN, Roberto M. Vegetação. In: IBGE. Geografia do Brasil: Região Sul. Rio de Janeiro: 1990. p. $113-150$.

LINDENMAIER, Diogo de Souza; BUDKE, Jean Carlos. Florística, diversidade e distribuição espacial das espécies arbóreas em uma floresta estacional na bacia do rio Jacuí, sul do Brasil. Pesquisas: Série Botânica, São Leopoldo, n. 57, p.193-216, 2006.

LONGHI, Solon Jonas et al. Aspectos fitossociológicos de fragmento de floresta estacional decidual, Santa Maria, RS. Ciência Florestal, Santa Maria, v. 10, n. 2, p.59-74, 2000.

LONGHI, Solon Jonas et al. Composição florística e estrutura da comunidade arbórea de um fragmento florestal no município de Santa Maria-Brasil. Ciência Florestal, Santa Maria, v. 9, n. 1, p.115-133, 1999. 
MACHADO, Paulo Fernando dos Santos; LONGHI, Solon Jonas. Aspectos florísticos e fitossociológicos do "Morro do Elefante", Santa Maria, RS. Centro de Ciências Rurais, Santa Maria, n. 20, p.261-280, 1990.

MARCHIORI, José Newton Cardoso. Fitogeografia do Rio Grande do Sul: enfoque histórico e sistemas de classificação. Porto Alegre: EST, 2002.

MARCUZZO, Suzane Bevilacqua et al. Comparação entre áreas em restauração e área de referência no Rio Grande do Sul, Brasil. Árvore, Viçosa, v. 38, n. 6, p.961-972, 2014.

MARCUZZO, Suzane Bevilacqua; ARAÚJO, Maristela Machado; LONGHI, Solon Jonas. Estrutura e relações ambientais de grupos florísticos em fragmento de floresta estacional subtropical. Árvore, Viçosa, v. 37, n. 2, p.275-287, 2013.

MARKUS, Eloísa. Estrutura arbórea da mata ciliar como indicador ambiental em propriedades leiteiras com floresta estacional decidual. 2014. 93 f. Dissertação (Mestrado) - Curso de Mestrado em Ambiente e Desenvolvimento, Programa de Pósgraduação Stricto Sensu, Centro Universitário Univates, Lajeado, 2014.

MARKUS, Eloísa; FREITAS, Elisete Maria de. Florística arbórea de uma porção de mata de encosta do Morro da Harmonia, Teutônia, Rio Grande do Sul, Brasil. Pesquisas: Série Botânica, São Leopoldo, n. 62, p.263-272, 2011.

MELO, Nilmar Azevedo de; PUTZKE, Marisa Terezinha Lopes; PUTZKE, Jair. Florística e fitossociologia no Morro do Botucaraí, município de Candelária, RS - Brasil. Caderno de Pesquisa: série Biologia, Santa Cruz do Sul, v. 26, n. 1, p.15-28, 2014.

MILANESI, Lucas de Souza; LEITE, Sérgio Luiz de Carvalho. Fitossociologia de espécies arbóreas em dique marginal de floresta ribeirinha no Rio Grande do Sul, Brasil, e comparação com ambientes aluviais e não aluviais. Revista Brasileira de Biociências, Porto Alegre, v. 12, n. 2, p.72-80, 2014.

MUNDELESKI, Everton; SCHMITZ, José Antônio Kroeff; BIONDO, Elaine. Estudo ambiental da microbacia do Arroio Jacarezinho (Nova Bréscia e Encantado, RS) com ênfase na mata ciliar e na qualidade da água. Caderno de Pesquisa: série Biologia, Santa Cruz do Sul, v. 20, n. 3, p.44-62, 2008.

MYERS, Norman et al. Biodiversity hotspots for conservation priorities. Nature, London, n. 403, p.853-858, 24 fev. 2000.

NAUJORKS, Eduarda; LAINDORF, Bruna Lucia; PUTZKE, Jair. Levantamento fitossociológico de vegetação ciliar do Arroio Andreas na localidade de Vera Cruz, RS, Brasil. Caderno de Pesquisa: série Biologia, Santa Cruz do Sul, v. 27, n. 2, p.6-19, 2015.

RAMBO, Balduíno. A Fisionomia do Rio Grande do Sul. 3a . ed. São Leopoldo: UNISINOS, 1994.

REMPEL, Claudete; SUERTEGARAY, Dirce Maria Antunes; JASPER, André. Aplicação do sensoriamento remoto para determinação da evolução da mata nativa da bacia hidrográfica do Rio Forqueta - RS entre 1985 e 1995 . Pesquisas: Série Botânica, São Leopoldo, v. 2, 2001.

RIO GRANDE DO SUL. BRENA, Doádi Antônio; SEMA/RS (Secretaria Estadual do Meio Ambiente do Rio Grande do Sul); UFSM (Universidade Federal de Santa Maria; DEFAP (Departamento de Florestas e Áreas Protegidas) (Org.). Relatório final do inventário florestal contínuo do Rio Grande do Sul. Santa Maria: UFSM, 2001. 701 p. Disponível em: <http://coralx. ufsm.br/ifcrs/frame.htm>. Acesso em: 4 maio 2014.

ROVEDDER, Ana Paula Moreira et al. Relação solo-vegetação em remanescente da floresta estacional decidual na Região Central do Rio Grande do Sul. Ciência Rural, Santa Maria, v. 44, n. 12, p.2178-2185, 2014.

SCCOTI, Marta Silvana Volpato et al. Mecanismos de regeneração natural em remanescente de floresta estacional decidual. Ciência Florestal, Santa Maria, v. 21, n. 3, p.459-472, 2011.

SCCOTI, Marta Silvana Volpato. Dinâmica da vegetação em remanescente de floresta estacional subtropical. 2012.177 f. Tese (Doutorado) - Curso de Pós-graduação em Engenharia Florestal, Centro de Ciências Rurais, Universidade Federal de Santa Maria, Santa Maria, 2012.

SCHÄFFER, Wigold Bertoldo et al (Ed.). Mata Atlântica: patrimônio nacional dos brasileiros. Brasília: MMA, 2000. 408 p. (Biodiversidade, 34). 
SCHUMACHER, Mauro Valdir et al (Org.). A Floresta Estacional Subtropical: caracterização e ecologia no rebordo do Planalto Meridional. Santa Maria: Pallotti, 2011a. 320 p.

SCHUMACHER, Mauro Valdir et al. Espécies predominantes na deposição de serapilheira em fragmento de floresta estacional decidual no Rio Grande do Sul. Ciência Florestal, Santa Maria, v. 21, n. 3, p.479-486, 2011 b.

SCIPIONI, Marcelo Callegari et al. Análise dos padrões florísticos e estruturais de uma comunidade arbórea-arbustiva em um gradiente de solo e relevo. In: SCHUMACHER, Mauro Valdir et al. A floresta estacional subtropical: caracterização e ecologia no rebordo do Planalto Meridional. Santa Maria: Pallotti, 2011. Cap. 5. p. 85-104.

SCIPIONI, Marcelo Callegari et al. Distribuição do compartimento arbóreo em gradiente de relevo e solos na encosta Meridional da Serra Geral, RS. Ciência Rural, Santa Maria, v. 40, n. 6, p.1295-1301, 2010.

SCIPIONI, Marcelo Callegari et al. Regeneração natural de um fragmento da floresta estacional decidual na Reserva Biológica do Ibicuí-mirim (RS). Floresta, Curitiba, v. 39, n. 3, p.675-690, 2009.

SCIPIONI, Marcelo Callegari. Análise fitossociológica de um fragmento de floresta estacional em uma catena de solos no Morro do Cerrito, Santa Maria, RS. Ciência Florestal, Santa Maria, v. 22, n. 3, p.457-466, 2012.

SCIPIONI, Marcelo Callegari. Gradiente ambiental em comunidades arbóreas no baixo rio Jacuí. Ciência Rural, Santa Maria, v. 45, n. 10, p.1802-1808, 2015.

SCIPIONI, Marcelo Callegari. Padrões ambientais e ecológicos de uma floresta estacional decidual sobre uma formação sedimentar na depressão central do Rio Grande do Sul. 2012. 158 f. Tese (Doutorado) - Curso de Pós-Graduação em Engenharia Florestal, Setor de Ciências Agrárias, Universidade Federal do Paraná, Curitiba, 2012.

SCIPIONI, Marcelo Callegari; GALVÃO, Franklin; LONGHI, Solon Jonas. Composição florística e estratégias de dispersão e regeneração de grupos florísticos em florestas estacionais deciduais no Rio Grande do Sul. Floresta, Curitiba, v. 43, n. 2, p.241-254, 2013.

SPELLMEIER, Jaqueline. Efeito do pastejo sobre a composição e estrutura da vegetação de um banhado no município de Estrela - RS. 2008. 62 f. Dissertação (Mestrado) - Curso de Pós-graduação em Ambiente e Desenvolvimento, Centro Universitário Univates, Lajeado, 2008.

SPELLMEIER, Jaqueline; PÉRICO, Eduardo; FREITAS, Elisete Maria de. Composição florística de um banhado no município de Estrela/Rio Grande do Sul. Pesquisas: Botânica, São Leopoldo, v. 60, p.367-381, 2009.

SÜHS, Rafael Barbizan; BUDKE, Jean Carlos. Spatial distribution, association patterns and richness of tree species in a seasonal forest from the Serra Geral formation, southern Brazil. Acta Botanica Brasilica, Belo Horizonte, v. 3, n. 25, p.605-617, 2011.

SÜHS, Rafael Barbizan; PUTZKE, Jair; BUDKE, Jean Carlos. Relações florístico-geográficas na estrutura de uma floresta na região central do Rio Grande do Sul, Brasil. Floresta, Curitiba, v. 40, n. 3, p.635-646, 2010.

TABARELLI, Marcelo. Flora arbórea da floresta estacional baixo-montana no município de Santa Maria, RS, Brasil. In: CONGRESSO NACIONAL SOBRE ESSÊNCIAS NATIVAS, 2, 1992, São Paulo. Anais... São Paulo: Instituto Florestal, 1992. p. $260-268$.

TEIXEIRA, Marelise et al. Estrutura da comunidade arbórea de um fragmento de mata ciliar do Rio Taquari, Colinas, Rio Grande do Sul. Jovens Pesquisadores, Santa Cruz do Sul, v. 4, n. 1, p.19-31, 2014.

VACCARO, Sandro. Caracterização fitossociológica de três fases sucessionais de uma floresta estacional decidual, no município de Santa Tereza - RS. 1997. 104 f. Dissertação (Mestrado) - Curso de Pós-graduação em Engenharia Florestal, Universidade Federal de Santa Maria, Santa Maria, 1997.

VACCARO, Sandro. Crescimento de uma floresta estacional decidual, em três estágios sucessionais, no município de Santa Tereza, RS, Brasil. 2012. 157 f. Tese (Doutorado) - Curso de Pós-graduação em Engenharia Florestal, Centro de Ciências Rurais, Universidade Federal de Santa Maria, Santa Maria, 2012. 
VACCARO, Sandro; LONGHI, Solon Jonas; BRENA, Doádi Antônio. Aspectos da composição florística e categorias sucessionais do estrato arbóreo de três subseres de uma floresta estacional decidual, no município de Santa Tereza - RS. Ciência Florestal, Santa Maria, v. 9, n. 1, p.1-18, 1999.

ZERWES, Cristian Mateus. Estrato arbóreo de fragmentos de floresta estacional decidual submontana em propriedades produtoras de leite: uso de dados fitossociológicos para diagnóstico de sustentabilidade. 2016. 165 f. Dissertação (Mestrado) - Curso de Mestrado em Ambiente e Desenvolvimento, Programa de Pós-graduação Stricto Sensu, Centro Universitário Univates, Lajeado, 2015.

Cristian Mateus Zerwes
Biólogo da Geoambiental Consultoria e Licenciamento Ltda, Lajeado, RS, Brasil
E-mail: cristianzerwes@universo.univates.br
Participação do autor:
Aquisição, análise e interpretação de dados e redigiu o trabalho
Claudete Rempel
Universidade do Vale do Taquari - Univates, Lajeado, RS, Brasil
E-mail:crempel@univates.br
Contribuições substanciais para a concepção do trabalho, análise ou interpretação

\section{Janaina Kollet Schneider}

Colégio Sinodal Gustavo Adolfo, Lajeado, RS, Brasil E-mail: janakollet@hotmail.com

Participação do autor:

Contribuições substanciais para a concepção do trabalho, análise ou interpretação de dados ;

\section{Leila Teresinha Maranho}

Universidade Positivo, Curitiba, Paraná, Brasil

E-mail:maranho@up.edu.br

Participação do autor:

Realizou uma revisão substancial. 